Article

\title{
Language that Supports Sustainable Development: How to Write about People in Universal Design Policy
}

\author{
Stina Ericsson ${ }^{1, *(\mathbb{D})}$, Daniel Wojahn ${ }^{1}$, Ida Sandström ${ }^{2}$ and Per-Olof Hedvall ${ }^{3}$ (i) \\ 1 Department of Swedish, University of Gothenburg, 40530 Gothenburg, Sweden; daniel.wojahn@gu.se \\ 2 Department of Architecture and Built Environment, Lund University, 22100 Lund, Sweden; \\ ida.sandstrom@arkitektur.lth.se \\ 3 Department of Design Sciences, Lund University, 22100 Lund, Sweden; per-olof.hedvall@certec.lth.se \\ * Correspondence: stina.ericsson@svenska.gu.se
}

Received: 30 September 2020; Accepted: 13 November 2020; Published: 17 November 2020

\begin{abstract}
Universal Design (UD) is a design approach that recognises and anticipates diversity as a fundamental human condition. UD is also frequently referred to in relation to the social dimension of sustainable development. Central to both UD and sustainability is the way "everyone," as the target of UD and sustainability goals, is understood. The purpose of the study is to identify how UD's "everyone" is conceptualised in Swedish UD policy and to provide a set of recommendations for how to categorise people with regards to UD. A qualitative text analysis is used, which investigates semiotic modes in relation to the content, form, and social relations of texts. Based on the analysis, two challenges for UD policy are identified: (i) how to convey that UD is design for everyone, and (ii) how to move away from a thought pattern of norm and deviation. Seven recommendations for how to approach categorisations of people in UD policy are formulated. We argue that an adoption of UD has the potential to bring about sustainable living environments for all, if integrated with social, economic, environmental, and spatial dimensions of development, but that in order for this to succeed, careful attention needs to be paid to how UD is conceptualised, and a radically different way of categorising people is necessary.
\end{abstract}

Keywords: Universal Design; categorisation; sustainability; language; policy; recommendations; disability

\section{Introduction}

Sustainable societies take everyone's needs, rights, abilities, and contributions into account. This means that a sustainable society is built and designed with everyone in mind, on all levels, and that everyone can participate in all the ways that they have the potential to do. In this, the conceptualisation of "everyone" is absolutely central; that is, who, in practice, is considered to be "everyone" - when transportation is being developed, when eHealth services are devised, when educational and cultural institutions are designed, and so on. While recognising that sustainable development necessarily requires the integration of social, economic, environmental, and spatial dimensions of development [1], this article focuses on the social dimension. Specifically, the article deals with the issue of who is seen as "everyone" in Swedish public policy and how this promotes or hinders the social dimension of sustainable development.

The role of language in conceptualising and conveying understandings, such as that of "everyone", is indispensable. Societal understandings of "everyone" shape how we talk about and communicate ideas of everyone, and this-language and communication-in turn influence how and for whom society is designed and built. Bluntly put, if plans for the design of various aspects of society include a poor understanding of who all members of society are, chances are slim that societal services and products will be usable by everyone. It is only when everyone is taken into account that a 
truly sustainable society for all can be achieved. In order to increase society's chances of reaching this goal, we need to critically examine how "everyone" is actually understood, which is what this study undertakes.

The study takes the UN 2030 Agenda Sustainable Development Goals [2] as its starting-point. Specifically, goals 10 and 11 (reduced inequalities and sustainable cities and communities) constitute our target. Among these, we highlight the following subgoals:

- "By 2030, empower and promote the social, economic, and political inclusion of all, irrespective of age, sex, disability, race, ethnicity, origin, religion, or economic or other status" (10.2).

- "By 2030, ensure access for all to adequate, safe, and affordable housing and basic services ..." (11.1).

- "By 2030, provide access to safe, affordable, accessible, and sustainable transport systems for all, improving road safety, notably by expanding public transport, with special attention to the needs of those in vulnerable situations, women, children, persons with disabilities, and older persons" (11.2).

- "By 2030, provide universal access to safe, inclusive, and accessible, green and public spaces, in particular for women and children, older persons, and persons with disabilities" (11.7).

Subgoals 11.1, 11.2, and 11.7 concern housing, basic services, transport systems, and public spaces. These are all designed, and as such they carry cultural values and norms, for instance, regarding how they are accessed, how movement through them is enabled, how communication in them is made possible, and so on. Subgoal 10.2 concerns inclusion across social, economic, and political domains.

Taken together, the goals have a clear aim of, on the one hand, providing for "all" human beings across the globe, and, on the other hand, to ensure that particular attention is paid to specific groups of people. These specific groups of people are "women," "children" (also as one group, "women and children"), "persons with disabilities," and "older persons." Groups of people are also suggested through the mention of the categories of "age", "sex", "disability", "race", "ethnicity", "origin", "religion", "economic status" and "other status." These mentions of groups of people mean that some subcategorisations of "all" are made relevant, and that it is seen as necessary to make certain categorisations of people in order to achieve the goals of global sustainability.

The goals also show that categorisations of people enter into all aspects of sustainable development-social, economic, and political dimensions, including housing and basic services, transport systems, and public spaces. This can be seen as an illustration of how social, economic, environmental, and spatial dimensions of sustainable development [1] interact.

In 2006, United Nations launched the UN Convention on the Rights of Persons with Disabilities (CRPD), where Universal Design (UD) is brought forward as a principal strategy towards building an open and inclusive society [3]. Today, UD is on the rise on a global level, much because of the worldwide adoption of the CRPD. UD is also frequently referred to in relation to "sustainability" and particularly to "social sustainable development", because of their common goals of "inclusion", "access" and "participation" [4].

UD is a rather new term that arose in the USA in the 1980s [5]. At its core, UD is a design approach that recognises and anticipates diversity as a fundamental human condition, to acknowledge, cherish, and celebrate when creating new design. UD shares its ideals and concepts with "Inclusive Design" and "Design for All". The original definition of UD is: "The design of products and environments to be usable by all people, to the greatest extent possible, without the need for adaptation or specialized design" [5]. "Design" is here understood as both the design process ("to design") and its end result ("a design").

Adopting UD entails a shift in categorisation of end users, where UD moves beyond "accessibility" that often has persons with disabilities as its target group, to encompass all people, based on an understanding of "the process of disablement as more pervasive and universal, one that can potentially encompass all human beings" [6] (p. 440). Hamraie explains that adopting UD means no longer 
designing for the "normate template", i.e., the average body, but instead for a range of users, which involves a radically different way of conceptualising users [7]. Thus, UD means moving beyond the idealistic and problematised view of the user as a neutral person without age, gender, social class, etc. $[7,8]$.

Both the CRPD and the UN Agenda 2030 have reached a significant level of adoption globally. On a national level, there has been a shift in recent years towards UD in Swedish disability policy. Sweden ratified the CRPD in 2008 and ten years later, in 2017, the Swedish Government proposed a new national objective for Sweden's disability policy with UD as a core principle. This was followed up in 2018 with a new proposed policy for architecture and design [9], stressing the importance of UD. As a design approach, UD combines social, economic, and environmental dimensions of sustainable development policy [10]. While we focus on the social dimension here, it is clear that both UD and sustainability crucially depend on the integration of several dimensions.

The aim of the study is to identify how UD's "everyone" is conceptualised in Swedish UD policy and to provide a set of recommendations for how to categorise people with regards to UD. The study assumes that understanding who UD is intended for, and in what ways, ultimately determines UD's chances of creating sustainable living environments for all. Importantly, policy documents such as those analysed here are politically established and enforced documents with real-life consequences, determining allocations of economic resources and the design of our societies, including who will ultimately be able to participate in society and in what ways. Seeing language as both reflecting and constituting society, our study aligns with critical approaches to discourse analysis [11]. From this perspective, the study of language is the study of society, and investigating meaning is a prerequisite for changing society into a more equitable and sustainable one. The study is also an interdisciplinary one, combining Linguistics, Architecture, and Design sciences.

Based on the results, we discuss possible implications of different ways of categorising people in relation to UD, by formulating a set of recommendations for language that supports sustainable development with regard to categorisations of people. The recommendations are intended for anyone writing policy documents, visions, strategies, etc., at national, regional, and municipal levels, which concern disability policy, Universal Design, urban planning and development, diversity, human rights, inclusion, and accessibility.

Approaching categorisations is a prerequisite for unpicking conceptualisations of UD's "everyone". In this article, we talk about "categorisations" rather than "categories" to emphasise the active processes that are involved [12], that is, categorisations are always done to someone and done by someone, as opposed to something already existing outside of social relations. Importantly, categorisations value certain perspectives and silence others, thus giving advantages to some and disadvantages to others [13]. Additionally, categorisation is often being done in an invisible way, which makes scientific inquiry into categorisations imperative [13]. We wish to emphasise that multiple categorisations, including no categorisation, are always potentially possible in any given situation, and people can always be categorised in different ways. There also seems to be evidence that the way people categorise others into different groups is not inevitable-people categorise others in different ways depending on the type of information given, even regarding what may appear to be stable categorisations such as race [14].

As we saw above, categorisations of people, such as the ones in the UN Agenda for Sustainable Development [2], can be expressed through linguistic labels such as "persons with disabilities", "older people", "women and children" and so on. One facet of such linguistic labels is the set of people that they are intended to refer to. Another facet is the values signalled by the linguistic label itself. For instance, a label such as "persons with disabilities" can be contrasted with "persons with impairments" or "disabled people" $[7,15,16]$. Different arguments are used for and against different labels, in this case related to e.g., people-first usage ("people with disabilities") vs. identity-first usage ("disabled people") [17,18], including whether disability is seen to reside within the individual, 
or whether it is seen as something created by society, or by a mismatch between society and individual [19].

When recommendations regarding which linguistic labels to use and attempts to change the current situation are made, this is known as language policy or language planning [20-22]. In addition to terminology, language policy and planning may involve all linguistic levels including which language(s) to use in which areas in a multilingual society. Language planning is done by a number of different actors, including national and local governments, language councils, companies, health service providers, schools, and families [20,23]. Language planning can be done for several different reasons, of which one reason is particularly salient for categorisations of people: a desire to promote less discriminatory language use, thereby increasing equality in society. Replacing labels that categorise people by new labels may also involve an attempt at changing the set of values-the worldview-that come with a specific label [24]. Beyond language studies, policy studies investigates policy-making processes and the contents of policies, which may include recommendations for policy and practice $[25,26]$.

In contrast with language-planning research regarding which specific linguistic labels are used $[15,17,24]$, our study focuses on categorisations as such. That is, we will not have anything to say about whether, e.g., person-first or identity-first usage is to be preferred, but instead we put such categorisations in relation to other categorisations, concerning e.g., age or gender, or in relation to not categorising at all, thus investigating conditions of use for different types of categorisation, including non-categorisation. This is not to be taken as meaning that choices between different expressions is unimportant-quite the opposite, but it is not the focus of this particular study. Put another way, the recommendations are not about linguistic details, but rather concern ways of thinking and communicating, in order to promote ways of thinking and communicating about categorisations of people that support Universal Design and thereby sustainability.

As we stated above, the aim of the study is to identify how UD's "everyone" is conceptualised in Swedish texts from the public sector and to provide a set of recommendations for how to categorise people with regards to UD. The principal conclusions regarding how UD's "everyone" is conceptualised in this material are: (i) contrary to first appearances, UD is not presented as being for everyone, (ii) the idea of an average body is upheld in spite of UD's aim to design for a diversity of people, (iii) the different modes of language and image can be used for categorisations of people in relation to UD in different ways, and iv) UD's "everyone" can also be conveyed without categorising people. Based on these analytical results, we identify two overarching challenges for UD policy with regards to categorisations of people: (i) how to convey that UD is design for everyone, and (ii) how to move away from a thought pattern of norm and deviation. Based on these four principal conclusions and two challenges, we formulate seven recommendations for how to approach categorisations of people in UD policy. We argue that an adoption of UD has the potential to bring about sustainable living environments for all, in an integrated framework of social, economic, environmental, and spatial dimensions of development, but that in order for this to succeed, careful attention needs to be paid to how UD is conceptualised, and a radically different way of categorising people is necessary.

\section{Materials and Methods}

The materials analysed in this study are publicly available texts, including multimodal texts in the form of animated films, that concern Universal Design either as their main topic or as a perspective that is used in at least parts of the text. The texts originate, wholly or partly, from the Swedish public sector, and constitute the type of documents that would benefit from recommendations such as the ones that we develop in this article. The texts all have the potential to have far-reaching consequences for the development of Swedish society, affecting possibilities for sustainable participation of individuals in all aspects of life. Our study is part of a larger research project on Universal Design and categorisation, for which ethical vetting has been conducted and approved by the Swedish Ethical Review Authority, no. 2019-03704. 
Nine texts are included in the study. These are shown in Table 1. Four of the texts are issued by the Government of Sweden (texts 2, 3, 5, and 8). One text (text 1) is issued by the Swedish Government Offices and is the Swedish version of the Convention on the rights of persons with disabilities (CRPD), which is an early example of an official text in Swedish that mentions Universal Design. Two texts are from the government agency of the Swedish Agency for participation (texts 4 and 7). One text (text 6) is from the Swedish Association of Local Authorities and Regions, which is an employer's organisation that houses all of Sweden's 290 municipalities and 21 regions. A final text (text 9) is issued by the Swedish Standards Institute, which combines the public sector, industry, academia, and non-governmental organisations in the development of standards.

Table 1. Overview of the material used in the study.

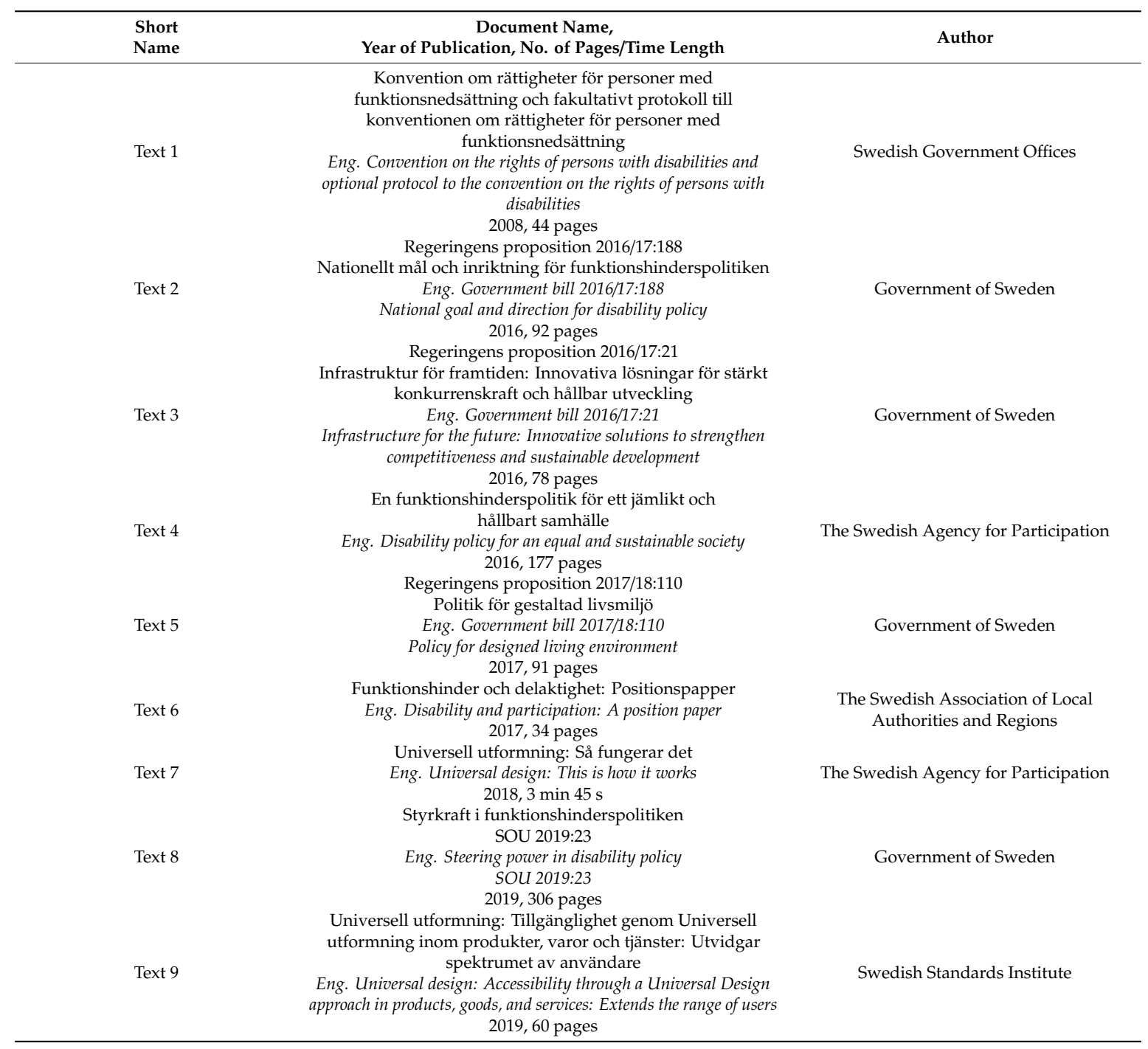

With the exception of the Swedish CRPD (text 1), which was published in 2008, all texts were published during 2016-2019, reflecting that interest in the concept of Universal Design has only risen very recently in Swedish policy. While text 7 is an animated film published on YouTube, all other texts are written documents with no illustrations pertinent to the categorisation of people. Document names in the table are given in the original Swedish followed by our translation into English, which may or may not correspond to the official English title of the document, where such a translation exists.

The study is a qualitative text analysis based in a Hallidayan tradition of investigating semiotic modes in relation to the content, form, and social relations of texts $[27,28]$. Specifically, as the study 
investigates representations of people, by identifying understandings of UD's "everyone", a multimodal critical discourse approach is used for the analysis of social actors in language and images [29,30]. Analysing which social actors are represented in texts and how they are represented in language and in different modes can reveal hidden meanings and values attached to social actors. Through its investigation of the role played by language in the social construction of disability, the study is also set within the field of disability and discourse analysis [31,32].

In practical terms, we began the analysis by searching for all instances of "universal design" (in Swedish "universell utformning") in the nine texts. In relevant textual passages surrounding "universal design", we then identified social actors in the form of references to people, as well as other things of interest, such as properties ascribed to the people references, actions that they are involved in, and textual properties such as headings and relations between different paragraphs. Based on such initial observations, potential themes across documents were identified. The next step in the analysis consisted of further selecting and refining salient themes, as represented in the Results section below.

All examples that are analysed in Results below are shown using our translations into English. The original Swedish formulations are found in Appendix A. The translations are not necessarily into fully idiomatic English, but are intended to capture some of the underlying Swedish, while hopefully still being comprehensible. For instance, the clausal ordering is maintained, and verbs and nouns are typically translated into the same parts of speech, when a more idiomatic rendering would involve larger changes. The guiding principle for the translation has been the study's focus on categorisations in these texts in relation to UD.

The Swedish texts that constitute the material for this study adhere to the guidelines of the Swedish National Board of Health and Welfare regarding terminology. The board recommends terminology based on the social model of disability [33,34], whereby a distinction is made between characteristics of the individual and the dis/ablisement that occurs in the relation between the environment and the individual. The former is referred to as person/er med funktionsnedsättning "person/s with functional lowering" in Swedish, which we have chosen to translate as person/people with impairments in this article, when we quote the material. The Swedish term for the latter is funktionshinder "functional hindrance." This term only appears in the material in the compound noun funktionshinderspolitik "functional hindrance policy", which we have translated as disability policy. Additionally, we use the terms disablised and disablising to refer to processes in social power relations [35], whereby a disablised body is not primarily a matter of a property of bodies, but rather a cultural framing of "corporeal deviance" and "what bodies should be or do" [36] (p. 6).

\section{Results}

Several of the texts include general and brief descriptions of what UD is. These are two representative examples, with categorisations of people highlighted using boldface (references are to the materials listed in Table 1, and original Swedish text extracts are found in Appendix A):

(1) Universal Design means that environments and products are to be designed so that they work for all people without a need for special adaptation. (Text 5, p. 63)

(2) Universal Design is about doing things the right way from the start and to avoid the creation of inaccessibility and thereby the need for adaptations afterwards to the greatest extent possible. The principle is based on that services and programs as well as products and environments are to be developed so that they can be used by all already from the start. (Text 8, p. 147)

Examples (1) and (2) convey that UD concerns all people and all, in formulations that are close to established descriptions of UD such as: "the design and composition of an environment so that it can be accessed, understood and used to the greatest extent possible by all people regardless of their age, size, ability or disability" [37]. Less typical in the material is the following formulation:

(3) Universal design means to start from design with an awareness of the variation that exists in the population. (Text 2, p. 46) 
Example (3) works slightly differently as compared to examples (1) and (2), by referring to the population and specifically saying that UD is about the variation that exists in the population. While the use of all (people), as in examples (1) and (2), portrays people as a unit, as a homogenous group, i.e., based on similarity or identity, example (3) talks about people through their variation, acknowledging and ascribing difference.

Something that can be gleaned already from these initial examples is a need to think both about all people as a whole, and about the variation that exists within that whole. In other words, in order to design for everyone, one needs to form an idea of the characteristics of the variation-of who the "range of users" [7] are, or of just how "age, size, ability, [and] disability" [37], and so on, matters in the design process. The remainder of the Results section shows how the texts tackle this task of writing about everyone and about variation, that is, how they conceptualise "everyone" in passages that concern UD. The results are presented using the following themes: UD is not for everyone, The normate template, Categorisation and modal affordances, and Not categorising people.

As an overall comment, it should be noted that many of the texts contain several ways of categorising people. The examples that are highlighted in the analysis should therefore not be seen as representative of, or evaluations of, individual texts as a whole.

\subsection{UD Is Not for Everyone}

In spite of initial or overarching formulations in the texts about UD being for everyone, it becomes clear from closer analysis of a vast number of text passages, that once the texts move away from the general formulations of all (people), and into subcategorisations, UD is actually not for everyone. This can be seen in three ways: UD is connected to only one categorisation, UD corresponds to accessibility, and Disability is the variation.

\subsubsection{UD Is Connected to Only One Categorisation}

The most obvious way in which it becomes evident in the material that UD is not for everyone, is when only one kind of categorisation is made in the texts-of "people with impairments." Consider this extract, which appears under the heading "Accessibility and participation":

(4) Physical and technical environments that local authorities and regions are in charge of, should be designed based on the principle of universal design and accessibility. Employees within local authorities and regions need knowledge about different needs and possible adaptations to promote accessibility and usability when meeting people with impairments. / . . / Information from local authorities and regions needs to be accessible for and usable by all. (Text 6, p. 15)

In this example, UD is introduced in the first sentence as an overall design principle to be followed. Social actors to benefit from UD are then referred to on two occasions in the example: people with impairments and all. All is an "indeterminate" [29] reference, meaning that social actors are represented as unspecified, without any information given about them. People with impairments is, instead, "determinate," with the identity of the social actors here being specified as involving having impairments. No other determinate references to social actors as the target of UD are used, meaning that having impairments is the characteristic that is associated with UD.

Consider next another example. This is a text passage that consists of five paragraphs under the heading "An inclusive society," taken from text 3 on infrastructure. This is the only place where UD is mentioned in this 78-page document. The example below shows snippets from all five paragraphs:

(5) Paragraph 1: Infrastructure can, through its design, contribute to a more cohesive society where the rights to accessibility for all are safeguarded. A large diversity of travellers with different preconditions and needs, e.g., children, young people, older people, girls, boys, women, and men raise high demands on an accessible society / . . / so that all can use it. Paragraph 2: This means e.g., that the transportation system has to be accessible for people with impairments. Therefore, universal design of the transportation system is pressing, as well as that the work 
with demands, guidelines, and standardisation for accessibility is given continued priority. / . . / Paragraph 3: The transportation system should be designed so that it answers to both women's and men's transportation needs. Women and men should be able to use the transportation system on equal terms and women's and men's values should be given equal weight. It is important to apply a gender equality perspective / . . / Paragraph $4:$ / . / better possibilities for children to use the transportation system / ... / Paragraph 5: The transportation system needs to meet the needs of people of different ages and with different backgrounds and economic situations. Clear and easily accessible information is important for all and in particular for people who are newly arrived and for an ageing population. The transportation system also needs to meet the transportation need of people in all parts of the country (Text 3, p. 34-35).

The social actors that are highlighted using boldface in example (5), are all textually portrayed as (actual or potential) users of the transportation system, that is, these are the social actors that the design of the transportation system needs to consider. The indeterminate all is used in the first and last paragraphs. All other highlighted references are determinate social actors: children, people with impairments, women, men, people with different economic situations, and so on, meaning that all of these groups of people get associated with using the infrastructure.

Looking at the textual structure of example (5), UD is mentioned only once, in the second paragraph. This is also the only paragraph that mentions people with impairments. Indeed, UD is introduced in this text as a consequence of the transportation system having to be accessible to people with impairments. UD is not connected to any of the other social actors, neither the determinate ones nor the indeterminate all. This, again, means that disability is the only categorisation that gets associated with UD, and in contrast with UD's stance of being design for everyone, UD comes across as design for people with impairments. This is all the more striking in example (5) as the text also contains other formulations that are highly reminiscent of UD thinking: a large diversity of travellers with different preconditions and needs, clear and easily accessible information is important for all. However, such formulations are not connected to UD in the text.

Other similar examples across the material as a whole contribute to a view of UD as not being for everyone, but rather restricted to disablised people.

\subsubsection{UD Corresponds to Accessibility}

A second way in which it becomes clear from the texts that UD is conceptualised as concerning a specific group of people and actually not everyone, is through the way UD gets associated or equated with accessibility, where accessibility is used in these texts in the sense of "design for people with disabilities" [38]. An example of UD being associated with accessibility can be seen in example (4) above. In that extract, UD and accessibility are combined into something that together form the basis for accessibility and usability for people with impairments (and also for the indeterminate all), without it being made clear what distinguishes UD from accessibility.

Another example is (5) above. In the second paragraph of this extract, therefore indicates a logical relationship between accessibility and UD, with UD introduced as a means to achieving accessibility. The same causal relationship can be seen in this example:

(6) The organisation shall use universal design in the whole organisation to achieve accessibility using the specifications in this document. (Text 9, p. 13)

Other examples in the material similarly show UD and accessibility framed in terms of each other, with UD introduced under headings that mention accessibility or as UD and accessibility fairly synonymous.

In all of these examples, the precise relationship between UD and accessibility, and in particular what distinguishes them, remains unclear, and, as accessibility is seen as "design for people with disabilities," the same conceptualisation is attached to UD. 


\subsubsection{Disability Is the Variation}

A third way in which the texts reveal that UD is not seen as for everyone, is through the way that UD's everyone is understood as "also disablised people," that is, where disablised social actors are seen as the addition that UD contributes and there is no actual consideration of a "range of users" [7]. Consider the following example, which appears under the heading "The principle of universal design":

(7) Universal design means that society is designed with an awareness of the variation that exists in the population and enables persons with impairments to carry out their everyday lives on the same conditions as people without impairments. (Text 2, p. 28)

While two social actors appear in this example-persons with impairments and people without impairments - they do so in strikingly different ways. First of all, UD is connected to the variation $/ \ldots$ / in the population, which, as we have seen, is one of the ways in which UD can be described. However, in example (7), UD is described as concerning, through effectuating change for, only persons with impairments. A comparison is made with the situation for the other social actor mentioned, people without impairments, a group portrayed as a yardstick in need of no aid measures. Through this, persons with impairments constitute the variation that UD is to be concerned with. In other words, this preserves a norm-deviation way of thinking, whereby people without impairments are the norm, and persons with impairments are the deviation —-the variation—in need of aid.

Another example is the following:

(8) The organisation shall, by taking human diversity including older people and people with impairments into account, strive to widen the spectrum of users of the products and services. (Text 9, p. 13)

Here, we can infer the existence of a set of users that are already considered without human diversity being taken into account, whereas the social actors referred to as older people and people with impairments constitute the diversity.

\subsection{The Normate Template}

As we have seen in the UD literature, UD involves moving away from designing for the average body, i.e., the "normate template," towards designing for a range of users [7]. However, the normate template still permeates the material that is analysed here. We will show three ways in which this occurs: through Explicit mention, the assumption of Normates unless otherwise specified, and Exclusion through everyone and some.

\subsubsection{Explicit Mention}

While disablised people are frequently explicitly mentioned in these texts, there are extremely few explicit mentions of the corresponding normative position, non-disablised people. One example of two almost identical formulations in the same text is found in (7) above: the social actor that constitutes the normate template is referred to as people without impairments. In the example, a binary distinction is made between people with and without impairments, implying that everyone can be sorted into either of these two categories. Besides, people without impairments is shown as the norm to which people with impairments are compared.

\subsubsection{Normates Unless Otherwise Specified}

The normate template can also be inferred implicitly. Consider example (5) again. Only one group of social actors is explicitly determined in relation to dis/ability: people with impairments. The other social actors referred to in the example-children, girls, men, people in all parts of the country, etc. - can thus implicitly be read as without impairments. That is, social actors are inferred to be without impairments unless otherwise specified. Clearly, children, girls, men, people in all parts of the country, etc. can 
certainly be assumed to be ablised or disablised in different ways and situations, but this is not what is conveyed in the text. Any linguistic or visual representation can include or exclude social actors [29], and the non-mention of ablising or disablising factors here, can be read as an exclusion that implicitly but powerfully turns all social actors other than people with impairments into normate templates with regards to dis/ability.

\subsubsection{Exclusion through Everyone and Some}

A hidden normate template can also be found in examples where an indeterminate "everyone" is related to another indeterminate term, expressed using e.g., "some" or "certain," or through determination. Consider (9) and (10):

(9) "universally designed" means the design of products, environments, programmes, and services such that they are to be usable by all to the greatest extent possible without a need for adaptation or special design. "Universally designed" should not exclude aid for single groups of people with impairments when needed. (Text 1, p. 7)

(10) apply the principle of so-called universal design, i.e., think strategically to ensure that products and services can be used by as many as possible and not beforehand exclude certain users. (Text 2, p. 68)

In example (9), the determinate (single groups of) people with impairments is connected to specific aid, and is a subset of all. Both types of social actors are portrayed as users, but other than that, very little information is given. Example (10) also concerns users, and the indeterminate certain users is a possible subset of as many as possible. Both subsets, i.e., both (single groups of) people with impairments and certain users, run the risk of being non-users. If we subtract these subsets from all and as many as possible, respectively, what remains are users that do not run the risk of being non-users, or, in other words, a form of normate template. However, the vagueness of the references to all social actors in these two examples make it difficult to unpack a normate template and the normate social actor remains elusive.

\subsection{Categorisation and Modal Affordances}

Taking different modal properties into account [29], this section shows some ways in which language and image afford categorisations of people with respect to UD. Language and image constitute the two different semiotic resources or modes of interest here. Written language is the only mode in the relevant passages in texts 1-6 and 8-9. Written language is also one of the modes in the film (text 7), in the form of subtitles. As the sound in the film is a voice-over whose content is identical to that of the subtitles, written and spoken language will be treated as a single language mode in this analysis. The second mode is the image, in the form of the basic animations used in the film (text 7).

Categorisations of people through language and image will be analysed regarding three ways in which the two modes differ: Linearity and simultaneity, Precision and polysemy, and Selection.

\subsubsection{Linearity and Simultaneity}

Language is linear: one word appears after the other, and one reference to a social actor is made after the other. Take, for instance, the following quote from example (5) above: A large diversity of travellers with different preconditions and needs, e.g., children, young people, older people, girls, boys, women, and men (Text 3, p. 34). By contrast, image-and also a combination of language and image-can represent several social actors simultaneously. Example (11) is taken from text 7 . The two screenshots (Figures 1 and 2) are taken from the images that are shown while the subtitle and voice-over says: We are all different; with different needs, preconditions, and abilities. 


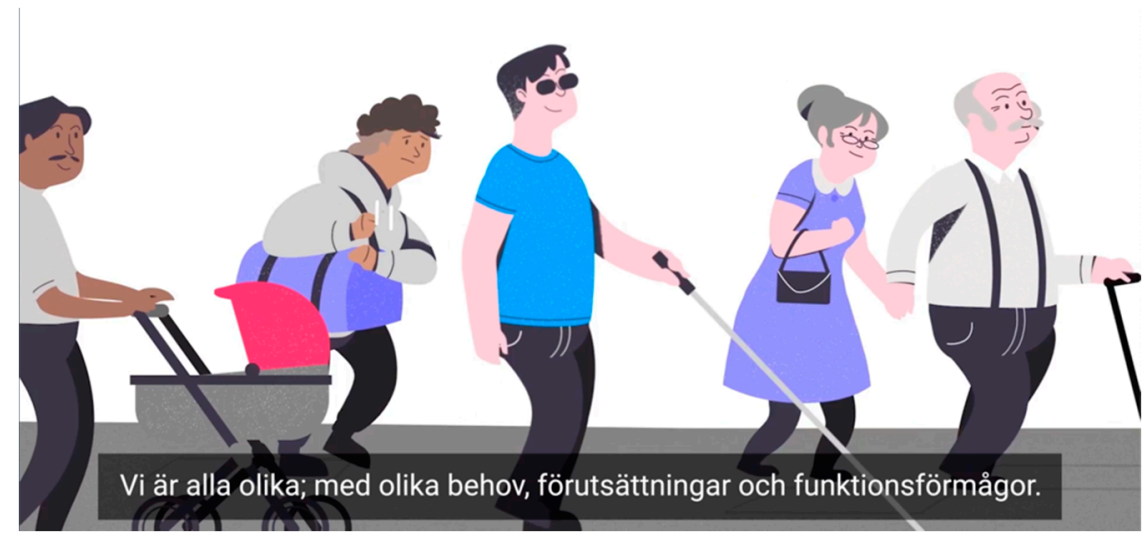

Figure 1. The left-hand start of the camera pan during the utterance in (11).

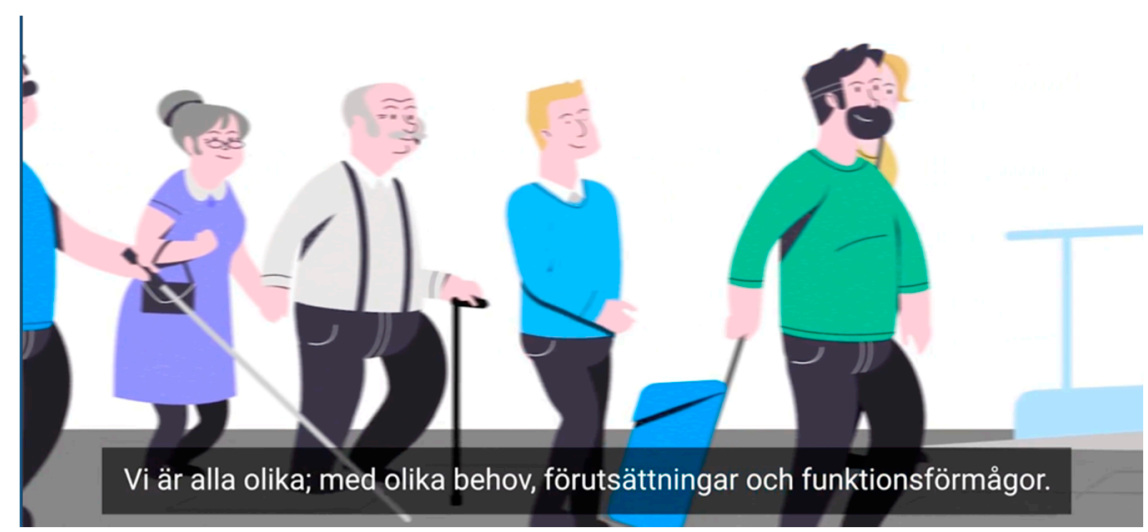

Figure 2. The right-hand end of the camera pan during the utterance in (11).

(11) We are all different; with different needs, preconditions, and abilities. (Text 7, 01:01-01:07)

In example (11) and Figures 1 and 2 the camera is shown to pan across the different people, from left to right, with about five people shown on the screen at the same time, in total seven clearly noticeable characters. The language mode refers to one social actor: the indeterminate all. At the same time, this is illustrated in the visual mode using several potential categorisations through the different people. Simultaneity in the visual mode also relates to the way each individual can be characterised in several different ways simultaneously. For instance, the person in the blue $t$-shirt may simultaneously be categorised regarding age, gender, weight, hair colour, skin colour, and so on.

Thus, this difference in linearity and simultaneity for language and image means differences in possibilities and restrictions regarding categorisations of people in the two modes. This will also be further explored in relation to precision and polysemy and selection below.

\subsubsection{Precision and Polysemy}

Language is precise whereas image is polysemous [30]. An enumeration of categorisations in the language mode such as in example (5)—children, young people, older people, girls, boys, women, and men-is very precise as to the specific categorisations being made. An image example such as (11) affords a number of categorisations, based on the fact that people can be categorised in multiple ways simultaneously. This means that categorisations in images are open to interpretation in a way that categorisations using language are not.

As we saw already regarding visual simultaneity above, the visually represented characters in Figures 1 and 2 can be characterised in several different ways. The language mode in this particular example gives an indication of - a form of instruction for-how the people are to be categorised: different needs, preconditions, and abilities may perhaps most directly point to categorisations such as 
having trouble walking (due to age-relate bodily deterioration, a heavy suitcase, etc.), needing an assistive cane, etc. However, a number of other categorisations can also be deduced, such as white-skinned, father, old woman, heterosexual, and so on. Whether intended by the author or not, all such categorisations form part of the polysemy here. For this image example specifically, as the film concerns UD and the language mode here states that we are all different, possibly the overall take-home message for the viewer is the existence of a diversity of categorisations, irrespective of precisely which categorisations these may be.

Figures 1 and 2 also interesting from a UD point of view because of the different types of categorisation that are being made. A language-mode categorisation such as used in example (5)—children, young people, older people, girls, boys, women, and men-are of a categorisation type called "identification" [29], which refers to social actors being described in terms of what they are, more or less permanently or unavoidably. Additionally, these categorisations are of the identification subtype "classification," which involves historically and culturally variable categories used by a society to divide people into groups [29]. Example (5) shows classifications related to gender and age. While classification can be done for the visual representations in Figures 1 and 2, other categorisations can also be relevantly made. Perhaps most relevantly, these are not identifications but "functionalisations" [29], whereby social actors are referred to in terms of an activity or something they do. In Figures 1 and 2 such functionalisations include moving, pushing a pram, carrying a suitcase, using an assistive cane, pulling a bag. With regards to UD, such combinations of functionalisations and identifications capture diversity in the meeting between people and the environment.

The contrast between language precision and image polysemy can also be seen when interpretations of categorisations in images such as Figures 1 and 2 are to be put into words. While the image can remain more open to interpretation, language has to choose between expressions such as person with a visual impairment, visually disabled person, person living with sight loss, and so on, all of which carry cultural values and norms.

\subsubsection{Selection}

All modes involve selection of what is to be shown or not-what is to be highlighted, backgrounded, or omitted. When the author of text 3 chooses to illustrate a large diversity of travellers in the first paragraph by children, young people, older people, girls, boys, women, and men, this selection signals that age and gender are of primary importance in this context (whether this was consciously intended by the author or not). [P]eople in all parts of the country are mentioned in the final sentence of the last paragraph (see example (5) above), giving this social actor considerably less importance. Such textual ordering is another way in which the linearity of the language mode functions with regard to categorisation.

In the visual mode, another example from text 7 shows an interesting use of selection in relation to categorisation. Example (12) and Figure 3 show the start of the film. 


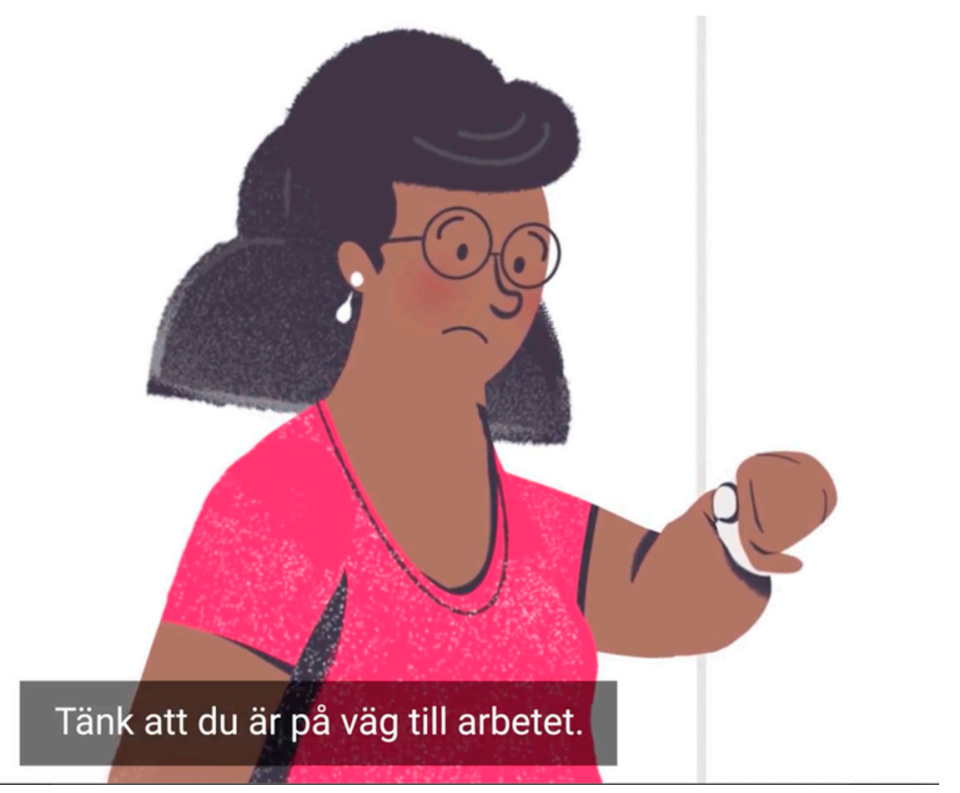

Figure 3. The image shown at the start of the film, when example (12) is being uttered.

(12) Imagine that you're on your way to work. (Text 7, 00:01-00:04)

The language mode in example (12) says Imagine that you're on your way to work. This contains a reference to one social actor, you, addressing the viewer. This social actor is also referenced as someone who has a job. Visually, as seen in Figure 3, several categorisations are potentially made, perhaps most notably: woman, middle-aged, black-haired, brown-skinned, with corrected vision. The film continues by explaining the difficulties that you experience in order to buy a bus ticket. Example (13) and Figure 4 show the next sequence, once you've finally succeeded in buying your bus ticket. The language mode conveys: But then you still can't get on the bus. The image now, for the first time, shows the whole body of you, making another categorisation relevant: wheelchair user.

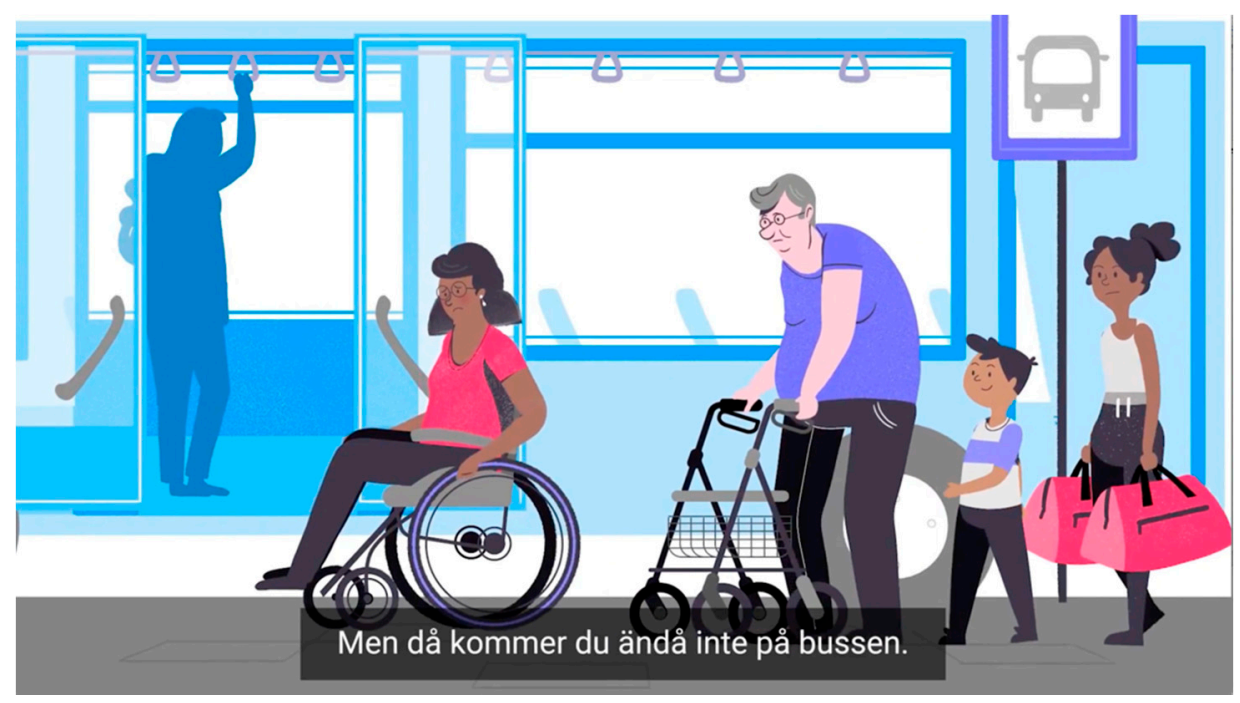

Figure 4. The image shown while example (13) is being uttered.

The difference between what parts of you are shown in Figures 3 and 4, respectively, shows how visual selection connects categorisation and UD: how you move your body when you are on your way somewhere, such as to work, is not necessarily relevant, and should ideally not have to be made relevant. The sequence highlights the situational aspects of categorisation, and the importance of what 
happens in the meeting between the individual and the environment. Other sequences in the film do the same thing, e.g., with the people in example (11) moving up ramps, stairs, and lifts, while wielding prams, carrying suitcases, using assistive canes, etc.

(13) But then you still can't get on the bus. (Text 7, 00:27-00:29)

\subsection{Not Categorising People}

So far, all of the examples have considered different ways of categorising people, and this has also been the focus of the study through its aim of investigating understandings of UD's "everyone." However, an alternative to categorising people is not to categorise people. Two such possibilities are shown here: Impersonalisation and Describing circumstances.

\subsubsection{Impersonalisation}

Not categorising people can be done through "impersonalisation," such as writing Australia (was doing something) instead of Australians (were doing something) [29]. That is, while in reality the actor performing an action is a person or a group of people, this is conveyed linguistically using a word or a phrase that does not, strictly speaking, refer to a person or people.

While no systematic investigation has been done of impersonalisation in the material, examples have been noted in passing. For instance, consider (14):

(14) The new national goal / . / is to / . / reach equality of living conditions and full participation for people with impairments in a society based on diversity. The goal shall contribute to increased gender equality and to the perspective of children's rights being heeded. (Text 5, p. 16)

In example (14) "personalisation" [29] is used for the social actor people with impairments, similar to other such examples we have already seen. This can be compared to gender equality in the second sentence, which is a form of impersonalisation in relation to e.g., (equality between) women and men. One possibility for impersonalisation of people with impairments similar to gender equality in example (14) could be to remove the reference to social actors, leaving: reach equality of living conditions and full participation in a society based on diversity. In that way, equality of living conditions and full participation act as impersonalisations, and as a way of talking about roughly the same thing as in the original example (14), but without categorising people.

\subsubsection{Describing Circumstances}

A second way in which categorisations of people can be avoided is by describing situational circumstances instead of ascribing differences only to people themselves. Consider this example:

(15) Every single user has their own profile of needs, properties, abilities, and preferences /.../. The abilities of most people change considerably during their lifetime, from childhood, to adulthood, and old age. Besides, changed circumstances, accidents, diseases, and other life-changing events can lead to considerable change regarding needs, properties, abilities, and preferences. Furthermore, the context of use for products, goods, and services can affect users' needs, properties, abilities, and preferences, and thereby the degree of accessibility and usability. Universal design considers all users' variation and circumstances, and aims at fulfilling their demands to the greatest possible extent. (Text 9, p. 7)

In example (15), references to social actors are made in the form of user(s) and people. While not quite as indeterminate as references such as everyone and some, they are not classifications like girls or old people. The text instead conveys the diversity of people and situations that UD targets by describing varying circumstances: changes during the course of life, and variations in the context of use.

A related example is the following: 
(16) A socially sustainable society is characterised by that it to the greatest extent possible is universally designed and therefore accessible and usable by all. If society is to be planned to be socially sustainable, the planning has to take into consideration that people are of different ages, ability, gender, and so on. (Text 8, p. 172)

As opposed to categorisations such as children, people with disabilities, and men, example (16) refers to people and describes their variation by mentioning the categories in relation to which people vary.

Describing circumstances can also include the variation that pertains to the physical environment and that affects the "two-way relation between people and their environment" [39] (p. 82), as different physical environments highlight different categorisations. Such aspects of the physical environment may include time of the day, weather, how crowded a place is, and so on.

\section{Discussion and Recommendations}

The aim of the study is to identify how UD's "everyone" is conceptualised in Swedish texts from the public sector and to provide a set of recommendations for how to categorise people with regards to UD. Regarding the first part of this aim, the results show (i) the way UD is treated in these texts which means that UD is actually not portrayed as being for everyone, (ii) the ways in which the "normate template" [7] is upheld in spite of UD's aim to design for a diversity of people, (iii) the different ways that the modes of language and image can be used for categorisations in relation to UD, and (iv) alternatives to categorisations by not categorising.

Clearly, UD policy cannot stop at the mention of UD as design for "everyone." Such a strategy would risk resulting in design that omits several perspectives. Instead, the results reveal a need for specification. The question then is how such specification is to be done in ways that promote UD and sustainability. We see two main and related obstacles in relation to the results of this study, obstacles that need to be overcome if UD policy is to be successful in achieving its aim of truly meaning design for everyone: (i) how to convey that UD is design for everyone, and (ii) how to move away from a thought pattern of norm and deviation.

The first obstacle is related to UD policy not showing UD as design for everyone. The radical potential of UD lies in its aim of designing for a diversity of people-for everyone. If UD policy continues to be narrowly conceived as design for people with impairments, this radical potential is lost. It might be argued that it makes sense for text passages that concern topics such as disability and participation to focus on people with impairments. However, even there, a great opportunity is lost to show the potential of UD. The unclear relationship between UD and accessibility that is evidenced in the texts further contributes to the lost potential. Such unclarity runs the risk of UD being equated with accessibility, and thereby seen as solvable in the same way. While accessibility certainly remains a pressing issue, accessibility can be achieved using special requirements, in stark contrast to the ethos of UD. If UD is conceived of as design only to meet special requirements of special groups of people, the current status quo regarding inequalities and unsustainability [2] will remain. What is needed is UD policy that considers a variety of people throughout.

The second obstacle that we see in relation to the results is related to the continued presence of a "normate template" [7] and the equation of variation with disability in UD policy. This preserves a norm-deviation way of thinking, whereby the existence of an average body is continued to be postulated, for whom the core design is intended, and any variation is seen as a deviation that is associated with extra cost and effectively becomes a burden. Such a norm-deviation way of thinking is, again, in opposition to the radical potential behind UD's diversity of people. A norm-deviation way of thinking hides the diversity that exists within any population. It also fails to recognise that needs and uses are not homogenous and static, nor invariably tied to specific groups of people. Rather, needs and uses vary both between and within individuals, whether situated or seen in a lifespan perspective.

We argue that these obstacles need to be overcome if UD policy is to have a chance of achieving its radical potential and of contributing to a sustainable living environment. Based on the results and the two obstacles, we now address the second part of the aim of the study: the formulation of a set of 
recommendations for how to categorise people with regards to UD. The recommendations do not take the form of a check list to be ticked off, but are instead formulated as a set of considerations to be made, as a support for ways of thinking about categorisations of people in relation to UD.

1. Decide whether to categorise people or not. It is not always necessary or desirable to categorise people at all. Using references to people can make the text more concrete, readable, and alive, but it also runs the risk of stereotyping and unnecessarily portraying people as unavoidably tied to specific categorisations. See Section 3.4.1 Impersonalisation and Section 3.4.2 Describing Circumstances for alternatives to categorising people.

2. Use a diversity of categorisations and use diversity as an aim in itself. UD explicitly targets human variation-the diversity that exists within any population. Using a diversity of categorisations of people can be an effective way of both showing this variation and of conveying UD's ideas. Seen from this perspective, each individual categorisation is not necessarily significant on its own-rather, it is the overall pattern of diversity that is meaningful. A diversity of categorisations can also be used as a reminder that everyone can be categorised in multiple ways, that no one ever belongs to just one category. Importantly, avoid static, homogenising, and stereotyping categorisations and avoid dividing a population into two distinct and opposite categories. Mix the order of categorisations if similar categorisations are made more than once, as another way of showing diversity. Use the analysis of images in Section 3.3.1 Linearity and Simultaneity, Section 3.3.2 Precision and Polysemy, and Section 3.3.3 Selection as inspiration for how to show diversity visually and also for how to achieve the same result using language.

3. Identify relevant categorisations. The point is not to include as many categorisations as possible in every text, but to identify which categorisations can be relevantly made in a specific context. Think about which categorisations are important for what you want to show or argue, making sure to include more than one categorisation. Specifically, identify what is absent, that is, any categorisations that are not being made but that ought or could relevantly be made.

4. Open up categorisations. Avoid referring to people using just "classifications," that is, categories such as age and gender that are used by a society to divide people into groups. Use categorisations of different types and aspects that affect people's interaction with the environment also in temporary ways, depending on the changing circumstances of both people and the physical environment. See Section 3.3 Categorisation and Modal Affordances and Section 3.4.2 Describing Circumstances for ideas.

5. Think diversity instead of norm-deviation. Use human variation as your starting point instead of assuming the existence of "average" and "non-average" bodies. Avoid creating us-them distinctions as these foster narratives about deviation. Use Section 3.4.2 Describing Circumstances and the analysis of visual categorisations in Section 3.3 Categorisation and Modal Affordances as inspiration. Avoid explicit and implicit references to the "normate template" (see Section 3.2 The Normate Template) and avoid portraying disability as the deviation from the norm (see Section 3.1.3 Disability Is the Variation).

6. Create narratives of difference rather than deviance. Consider the ways in which people differ from each other, and change the underlying thought model from deviance to difference. Use Section 3.3.3 Selection and Section 3.4.2 Describing Circumstances for inspiration.

7. Improve your text awareness. Where and how something is presented in a text influences how it is understood, whether this was your conscious intention or not. Take control of the interpretation of your text by applying some basic writing techniques. Specifically, regarding categorisations in relation to UD: (i) look at the textual context in the form of surrounding sentences, paragraphs, and headings to make sure that they together convey the ideas of UD (for a contrast, see e.g., examples (4) and (5) in Section 3.1.1 UD is Connected to Only One Categorisation), (ii) make sure to use the advantages of the modal affordances of the mode(s) you are using, whether language, image, or both (see Section 3.3 Categorisation and Modal Affordances). 
The recommendations are intended to be used together, so that the use of one recommendation may be influenced by the choices that one makes in relation to one of the other recommendations, and different recommendations may be given varying weight in different kinds of text, or even in different parts of the same text. The point that we wish to make here is that no communicative choices are innocent-all choices, all ways of categorising people, or not categorising them, have consequences that need to be considered. Authors need to be aware of the possible choices and their consequences, and the choices need to be made consciously in relation to the overarching goals of UD and sustainability.

In this article, we have shown how our combined approaches of Linguistics, Architecture, and Design sciences can be used to identify critical aspects of categorisations of people in UD policy. An adoption of UD has the potential to bring about a sustainable living environment for all, if integrated with social, economic, environmental, and spatial dimensions of development, but in order for this to succeed, careful attention needs to be paid to how UD is conceptualised, and a radically different way of categorising people is necessary.

Author Contributions: Conceptualisation, S.E., P.-O.H. and D.W.; methodology, S.E.; validation, S.E., P.-O.H., I.S. and D.W.; investigation, S.E.; resources, P.-O.H.; data curation, S.E.; writing-original draft preparation, S.E.; writing-review and editing, S.E., P.-O.H., I.S. and D.W.; project administration, S.E.; funding acquisition, S.E. and P.-O.H. All authors have read and agreed to the published version of the manuscript.

Funding: This research was funded by VINNOVA, the Swedish Governmental Agency for Innovation Systems, grant number 2018-05232.

Conflicts of Interest: The authors declare no conflict of interest. The funders had no role in the design of the study; in the collection, analyses, or interpretation of data; in the writing of the manuscript, or in the decision to publish the results.

\section{Appendix A}

All materials analysed in this article are in Swedish. To improve readability of the article we have chosen only to show translations into English in the main body of the article. This appendix contains the original formulations in Swedish for all examples. The examples are given the same numbers as the corresponding English translations in the main body of the article. References are to the texts listed in Table 1.

1. Med universell utformning menas att miljöer och produkter ska utformas så att de fungerar för alla människor utan att speciell anpassning behövs. (Text 5, p. 63)

2. Universell utformning handlar om att göra rätt från början och att i så stor utsträckning som möjligt undvika att skapa otillgänglighet och därmed behov av anpassningar i efterhand. Principen bygger på att såväl tjänster och program som produkter och miljöer ska utvecklas så att de kan nyttjas av alla redan från början. (Text 8, p. 147)

3. Universell utformning innebär att utgå från design med medvetenhet om den variation som återfinns i befolkningen. (Text 2, p. 46)

4. Fysiska och tekniska miljöer för verksamheter som drivs av kommuner, landsting och regioner bör utformas utifrån principen om universell utformning och tillgänglighet. Medarbetare inom kommuner, landsting och regioner behöver kunskap om olika behov och möjliga anpassningar för att också genom sitt bemötande främja tillgänglighet och användbarhet för personer med funktionsnedsättning. / . . / Information från kommuner, landsting och regioner behöver vara tillgänglig och användbar för alla. (Text 6, p. 15)

5. [Paragraph 1:] Infrastrukturen kan genom sin utformning bidra till ett mer sammanhållet samhälle där allas rätt till tillgänglighet värnas. En stor mångfald av resenärer med olika förutsättningar och behov, t.ex. barn, unga, äldre, flickor, pojkar, kvinnor och män, ställer höga krav på ett tillgängligt samhälle / . . / så att alla kan använda det. [Paragraph 2:] Det innebär bl.a. att transportsystemet ska vara tillgängligt för personer med funktionsnedsättning. Det är därför angeläget med en universell utformning av transportsystemet och att arbetet med krav, riktlinjer och standardisering för tillgänglighet får fortsatt prioritet. / . . / [Paragraph 3:] Transportsystemet ska vara utformat 
så att det svarar mot både kvinnors och mäns transportbehov. Kvinnor och män ska kunna använda transportsystemet på lika villkor och kvinnors och mäns värderingar ska tillmätas lika vikt. Det är viktigt att anlägga ett jämställdhetsperspektiv / . . / [Paragraph 4:] / . . / bättre förutsättningar för barn att använda transportsystemet / . . / [Paragraph 5:] Transportsystemet behöver tillgodose behoven hos människor i olika ålder och med olika bakgrund och ekonomiska förutsättningar. Tydlig och lättillgänglig information är viktigt för alla och särskilt för nyanlända och för en åldrande befolkning. Transportsystemet behöver också tillgodose transportbehovet för människor i alla delar av landet (Text 3, p. 34-35)

6. Organisationen ska använda universell utformning i hela organisationen för att uppnå tillgänglighet genom att utgå från de krav som anges i detta dokument. (Text 9, p. 13)

7. Universell utformning innebär att samhället utformas med medvetenhet om den variation som återfinns i befolkningen och möjliggör att personer med funktionsnedsättning får möjlighet att verka i vardagen på samma villkor som människor utan funktionsnedsättning. (Text 2, p. 28)

8. Organisationen ska, med beaktande av mänsklig mångfald inklusive äldre personer och personer med funktionsnedsättning, sträva efter att utvidga spektrumet av användare av produkterna och tjänsterna. (Text 9, p. 13)

9. "universellt utformade" betyder sådan utformning av produkter, miljöer, program och tjänster att de ska kunna användas av alla i största möjliga utsträckning utan behov av anpassning eller specialutformning. "Universellt utformade" ska inte utesluta hjälpmedel för enskilda grupper av personer med funktionsnedsättning där så behövs. (Text 1, p. 7)

10. tillämpar principen om s.k. universell utformning, dvs. tänker strategiskt för att säkerställa att produkter och tjänster kan användas av så många som möjligt och inte på förhand utesluter vissa användare. (Text 2, p. 68)

11. Vi är alla olika; med olika behov, förutsättningar och funktionsförmågor. (Text 7, 01:01-01:07)

12. Tänk att du är på väg till arbetet. (Text 7, 00:01-00:04)

13. Men då kommer du ändå inte på bussen. (Text 7, 00:27-00:29)

14. Det nya nationella målet /.../ är att /.../ uppnå jämlikhet i levnadsvillkor och full delaktighet för personer med funktionsnedsättning i ett samhälle med mångfald som grund. Målet ska bidra till ökad jämställdhet och till att barnrättsperspektivet ska beaktas. (Text 5, p. 16)

15. Varje enskild användare har en egen profil av behov, egenskaper, förmågor och preferenser / ... /. De flesta människors förmågor förändras väsentligt under livets gång, från barndom till vuxenliv och ålderdom. Dessutom kan förändrade omständigheter, olyckor, sjukdomar och andra livsförändrande händelser leda till en avsevärd förändring av behov, egenskaper, förmågor och preferenser. Vidare kan användningssammanhanget för produkter, varor och tjänster påverka användarnas behov, egenskaper, förmågor och preferenser och därmed graden av tillgänglighet och användbarhet. Universell utformning beaktar alla användares variationer och omständigheter, och syftar till att uppfylla deras krav i största möjliga utsträckning. (Text 9, p. 7)

16. Ett socialt hållbart samhälle utmärks av att det i största möjliga utsträckning är universellt utformat och därmed tillgängligt och användbart för alla. Ska samhället planeras utifrån att det ska vara socialt hållbart, måste planeringen ske mot bakgrund av att människor är olika i ålder, funktionsförmåga, kön och så vidare. (Text 8, p. 172) 


\section{References}

1. World Commission on Environment and Development. Our Common Future; Oxford University Press: Oxford, UK, 1987; ISBN 019282080X.

2. United Nations. Transforming Our World: The 2030 Agenda for Sustainable Development. 2015. Available online: https://sustainabledevelopment.un.org/content/documents/21252030\%20Agenda\%20for\% 20Sustainable\%20Development\%20web.pdf (accessed on 24 September 2020).

3. United Nations. Convention on the Rights of Persons with Disabilities and Optional Protocol. 2006. Available online: https://www.un.org/disabilities/documents/convention/convoptprot-e.pdf (accessed on 24 September 2020).

4. Vavik, T.; Keitsch, M.M. Exploring relationships between universal design and social sustainable development: Some methodological aspects to the debate on the sciences of sustainability: Exploring Relationships Between Universal Design and Social Sustainable Development. Sust. Dev. 2010, 18, 295-305. [CrossRef]

5. Steinfeld, E.; Maisel, J. Universal Design: Creating Inclusive Environments; John Wiley \& Sons, Inc: Hoboken, NJ, USA, 2012; ISBN 978-1-118-16845-5.

6. Gossett, A.; Mirza, M.; Barnds, A.K.; Feidt, D. Beyond access: A case study on the intersection between accessibility, sustainability, and universal design. Disabil. Rehabil. Assist. Technol. 2009, 4, 439-450. [CrossRef] [PubMed]

7. Hamraie, A. Building Access: Universal Design and the Politics of Disability; University of Minnesota Press: Minneapolis, MN, USA, 2017; ISBN 978-1-5179-0163-9.

8. Sandström, I. Towards a Minor Urbanism: Thinking Community without Unity in Recent Makings of Public Space; Department of Architecture and Built Environment, Lund University: Lund, Sweden, 2019; ISBN 978-91-7740-119-3.

9. Government Offices of Sweden. Policy for Designed Living Environment, 2017/18:110. Available online: https:/www.government.se/4a734a/contentassets/c008469d86b848f3918a1efcd7d7fb2f/ policy-for-designed-living-environment.pdf (accessed on 24 September 2020).

10. Malik, K.; Mikołajczak, E. Senior Housing Universal Design as a Development Factor of Sustainable-Oriented Economy. Sustainability 2019, 11, 7093. [CrossRef]

11. Fairclough, N.; Mulderrig, J.; Wodak, R. Critical Discourse Analysis. In Discourse Studies: A Multidisciplinary Introduction; Sage: London, UK, 2011; Volume 2011, pp. 357-378. ISBN 978-1-84860-649-4.

12. Hornscheidt, A. Intersectional challenges to gender studies: Gender studies as a challenge to intersectionality. In Gender Delight: Science, Knowledge, Culture, and Writing...: For Nina Lykke; The Tema Genus Series of Interdiscplinary Gender Research in Progress and Transformation; Linköping University: Linköping, Sweden, 2009; pp. 33-46. ISBN 978-91-7393-594-4.

13. Bowker, G.C.; Star, S.L. Sorting Things Out: Classification and Its Consequences; Inside technology; MIT Press: Cambridge, MA, USA, 1999; ISBN 978-0-262-02461-7.

14. Wheeler, M.E.; Fiske, S.T. Controlling Racial Prejudice: Social-Cognitive Goals Affect Amygdala and Stereotype Activation. Psychol. Sci. 2005, 16, 56-63. [CrossRef] [PubMed]

15. Kenny, L.; Hattersley, C.; Molins, B.; Buckley, C.; Povey, C.; Pellicano, E. Which terms should be used to describe autism? Perspectives from the UK autism community. Autism 2016, 20, 442-462. [CrossRef] [PubMed]

16. Noble, A.J.; Robinson, A.; Snape, D.; Marson, A.G. 'Epileptic', 'epileptic person' or 'person with epilepsy'? Bringing quantitative and qualitative evidence on the views of UK patients and carers to the terminology debate. Epilepsy Behav. 2017, 67, 20-27. [CrossRef] [PubMed]

17. Dunn, D.S.; Andrews, E.E. Person-first and identity-first language: Developing psychologists' cultural competence using disability language. Am. Psychol. 2015, 70, 255-264. [CrossRef] [PubMed]

18. Crocker, A.F.; Smith, S.N. Person-first language: Are we practicing what we preach? JMDH 2019, 12, 125-129. [CrossRef] [PubMed]

19. Garland-Thomson, R. Misfits: A Feminist Materialist Disability Concept. Hypatia 2011, 26, 591-609. [CrossRef]

20. Spolsky, B. Language Management; Cambridge University Press: Cambridge, NY, USA, 2009; ISBN 978-0-521-51609-9.

21. Spolsky, B. The Cambridge Handbook of Language Policy; Cambridge handbooks in language and linguistics; Cambridge University Press: Cambridge, NY, USA, 2012; ISBN 978-0-521-19565-2. 
22. Pauwels, A. Women Changing Language; Real language series; Longman: London, UK, 1998; ISBN 978-0-582-09961-6.

23. Hult, F.M.; Kupisch, T.; Siiner, M. Language Policy and Language Acquisition Planning, 1st ed.; Language Policy; Springer International Publishing: Cham, The Switzerland, 2018; ISBN 978-3-319-75963-0.

24. Vogel, A. To evaluate corpus planning. A case of a Swedish language policy action concerning terms for disability. Curr. Issues Lang. Plan. 2019, 21, 88-104. [CrossRef]

25. Simpson, R.L.; Mundschenk, N.A.; Heflin, L.J. Issues, Policies, and Recommendations for Improving the Education of Learners With Autism Spectrum Disorders. J. Disabil. Policy Stud. 2011, 22, 3-17. [CrossRef]

26. Plotner, A.J.; Marshall, K.J. Navigating University Policies to Support Postsecondary Education Programs for Students With Intellectual Disabilities. J. Disabil. Policy Stud. 2014, 25, 48-58. [CrossRef]

27. Halliday, M.A.K. Language as Social Semiotic: The Social Interpretation of Language and Meaning; Arnold: London, UK, 1979; ISBN 978-0-7131-5967-7.

28. Halliday, M.A.K.; Matthiessen, C.M.I.M. Halliday's Introduction to Functional Grammar, 4th ed.; Routledge: Abingdon, IL, USA, 2014; ISBN 978-0-415-82628-0.

29. Van Leeuwen, T. Discourse and Practice: New Tools for Critical Discourse Analysis; Oxford studies in sociolinguistics; Oxford University Press: Oxford, NY, USA, 2008; ISBN 978-0-19-532331-3.

30. Van Leeuwen, T. Critical discourse analysis and multimodality. In Contemporary Critical Discourse Studies; Contemporary studies in linguistics; Bloomsbury Academic: London, UK, 2017; pp. 281-295; ISBN 1-4742-9500-2.

31. Grue, J. Discourse analysis and disability: Some topics and issues. Discourse Soc. 2011, 22, 532-546. [CrossRef]

32. Grue, J. Disability and Discourse Analysis; Interdisciplinary disability studies; Ashgate: Burlington, VT, USA, 2015; ISBN 978-1-4724-3292-6.

33. Oliver, M. Social Work with Disabled People; Macmillan: Basingstoke, UK, 1983.

34. Oliver, M. The social model of disability: Thirty years on. Disabil. Soc. 2013, 28, 1024-1026. [CrossRef]

35. Campbell, F.A. 'Refleshingly Disabled': Interrogations into the Corporeality of 'Disablised' Bodies. Aust. Fem. Law J. 1999, 12, 57-80. [CrossRef]

36. Garland-Thomson, R. Extraordinary Bodies: Figuring Physical Disability in American Culture and Literature; Columbia University Press: New York, NY, USA, 1997; ISBN 978-0-231-10516-3.

37. What is Universal Design. Available online: http://universaldesign.ie/What-is-Universal-Design/ (accessed on 24 September 2020).

38. Henry, S.L.; Abou-Zahra, S.; Brewer, J. The role of accessibility in a universal web. In Proceedings of the 11th Web for All Conference on-W4A '14, Seoul, Korea, 7-9 April 2014; ACM Press: Seoul, Korea, 2014; pp. 1-4.

39. Lehtovuori, P. Towards Experiential Urbanism. Crit. Sociol. 2012, 38, 71-87. [CrossRef]

Publisher's Note: MDPI stays neutral with regard to jurisdictional claims in published maps and institutional affiliations.

(C) 2020 by the authors. Licensee MDPI, Basel, Switzerland. This article is an open access article distributed under the terms and conditions of the Creative Commons Attribution (CC BY) license (http://creativecommons.org/licenses/by/4.0/). 